\section{A FEW HAEMATOLOGICAL AND SEROLOGICAL PARAMETERS OF SIKA DEER, BARKING DEER AND GORAL AT A HIGH ALTITUDE ZOO}

\author{
K. Nagappa ${ }^{1}$, P.S. Girish ${ }^{1}$, A. Srivastava ${ }^{1}$, \\ J.P. Korde ${ }^{2}$, P. Bhatt ${ }^{1}$ and Sanwal ${ }^{3}$
}

${ }^{1}$ College of Veterinary and Animal Sciences, G.B. Pant University of Agriculture and Technology, Pantnagar Distt, Udham Singh Nagar, Uttaranchal 263145, India.

${ }^{2}$ Veterinary Officer, G.B. Pant High Altitude Zoo, Pantnagar Distt, Udham Singh Nagar, Uttaranchal 263145, India.

${ }^{3}$ Assistant Professor, Department of Veterinary Physiology, College of Veterinary and Animal Sciences, G.B. Pant University of Agriculture and Technology, Pantnagar, Distt, Udham Singh Nagar,

E-mail: ${ }^{2}$ jayantpkorde@rediffmail.com

Blood analysis is a common means of assessing nutritional, diseased and reproductive status of a free-ranging deer (Seal \& Busch, 1987; Wood et al., 1986). It is therefore imperative to establish reference values for blood characteristics of ungulates (DelGiudice et al., 1990) so as to compare at the time of adverse health status. In the present study, efforts are made to add the data with respect to haematological and serum biochemical parameters in these animals that are habituated to high altitudes.

Nainital Zoo $\left(29^{\circ} 24^{\prime} \mathrm{N} \& 7^{\circ} 28^{\prime} \mathrm{E}\right)$ is located at an altitude of $2075 \mathrm{~m}$. The ungulates in the zoo were captured by physical restraint by the trained zoo staff without causing much stress to the animals. Blood samples $(5 \mathrm{ml}$ each) were collected aseptically by jugular venipuncture using 18 gauze needles into a sterile tube containing ethylene di-amine tetra-acetic acid (EDTA) for haematological analysis, and into $10 \mathrm{ml}$ serum tubes for serum biochemical analysis. Haematological parameters were performed in the laboratory using standard procedures. Haemoglobin concentration was estimated by Sahli's haemometer using acid haematin method; packed cell volume (PCV) by microhaematocrit method; total erythrocyte count (TEC) by haemocytometer method and total leucocyte count (TLC) was performed by hemocytometer method Thoma's diluting fluid. The serum biochemical parameters were estimated using kits. Serum glucose was estimated by Glucoxidase Peroxidase method (GOD-POD) as described by Trinder, (1969), using reagents supplied by Beacon Diagnostics Pvt. Ltd., Navasar. Total serum protein was determined by Biuret method (King \& Wooton, 1959; Henry et al., 1974), reagents supplied by Beacon Diagnostics Pvt. Ltd., Navasar. Albumin and globulin were estimated by Bromocresol Green (BCG dye) method (Doumas \& Watson, 1971), using Crest Biosystems Reagents. Creatinine was estimated using Jaffe (modified) method as described by Schirmeister et al. (1964) and urea by enzymatic method using urease (Webster, 1977).

The random haematological and serum biochemical parameters estimated for the given species are detailed in the Tables 1 and Uttaranchal 263145, India (Corresponding author)

2. Haematological profile in female Sika Deer $(n=1)$ was found to be within normal range as reported by Kitchen (1978). In case of gorals, RBC and haemoglobin values were well within the normal range. These values were observed higher in the males $(\mathrm{n}=2)$ as compared to the females $(\mathrm{n}=2)$. Reiter et al. (1994) also observed significant sex-wise variation among gazelles with respect to $\mathrm{PCV}, \mathrm{Hb}, \mathrm{MCV}$, and $\mathrm{MCH}$, where the values were higher in males than in females. In case of barking deer, $\mathrm{Hb}, \mathrm{RBC}, \mathrm{PCV}$ values were also well within the normal range and were comparatively higher in the males $(n=2)$ than in the females $(n=2)$.

Serum biochemical profile in female Sika Deer was found to be within normal range with respect to serum total protein, albumin, globulin, creatinine and urea. In case of Barking Deer, serum glucose, total protein, globulin and creatinine were slightly higher in males compared to females. Similarly, Kovac et al. (1997) found no significant differences in juvenile Fallow Deer when evaluated by their gender. In case of gorals, males showed comparatively higher values of serum total protein, albumin, globulin and creatinine than the females. On the other hand, in gorals and barking deer, the urea concentration was higher than the males.

\section{REFERENCES}

DelGiudice, C.D., P.R. Krausmwn, E.S. Bellantani, M.C. Wallace, R.C. Etchberger and U.S. Seal (1990). Blood and urinary profiles of free-ranging desert mule deer in Arizona. Journal of Wildlife Diseases 26(1): 83-89.

Doumas, B.J. and W.A. Watson (1971). Clinical Chemistry Acta. 31: 87.

Henry, R.J., D.V. Cannaon and J.W. Winkelman (1974). Clinical Chemistry Principles and Techniques. $2^{\text {nd }}$ Edition. Harper and Row.

King, J. and Wooton (1959). Journal of Medical Laboratory Techniques 16: 265 .

Kitchen, H. (1978). Haematological values and blood chemistry for a varity of artiodactylids. In: Fowler, M.E. (Ed.). Zoo and Wildlife Medicine. W.B. Saunders Company, Philadelphia.

Kováè, G.J., I. Ciberej, H. Paulíková and Seidel (1997). Haematological indices in Fallow Deer. Acta Vetinaria Brno. 66: 203211.

Reiter, F.E., E.C. Delima and S.M. Mubarak (1994). The

Table 1. Haematological profile of Sika Deer, Goral and Barking Deer

\begin{tabular}{llllll}
\hline Parameters & $\begin{array}{l}\text { Sika Deer } \\
\text { Female }\end{array}$ & \multicolumn{2}{c}{ Goral } & \multicolumn{2}{c}{ Barking Deer } \\
& $(\mathbf{n = 1})$ & $(\mathbf{n = 2})$ & $\begin{array}{l}\text { Female } \\
(\mathbf{n}=\mathbf{2})\end{array}$ & $\begin{array}{l}\text { Male } \\
(\mathbf{n}=\mathbf{2})\end{array}$ & $\begin{array}{l}\text { Female } \\
(\mathbf{n}=\mathbf{2})\end{array}$ \\
\hline Hb $(\mathrm{g} / \mathrm{dl})$ & 14.00 & 11.60 & 8.40 & 13.00 & 12.00 \\
RBC $\left(10^{6} / \mu \mathrm{l}\right)$ & 7.00 & 5.80 & 4.30 & 6.50 & 6.00 \\
WBC $\left(10^{3} / \mu \mathrm{l}\right)$ & - & - & - & 8.83 & - \\
PCV $(\%)$ & 42.00 & - & - & 39.00 & 36.00 \\
\hline
\end{tabular}

Table 2. Serum profile of Sika Deer, Goral and Barking Deer

\begin{tabular}{|c|c|c|c|c|c|}
\hline \multirow[t]{2}{*}{ Parameters } & \multirow{2}{*}{$\begin{array}{l}\text { Sika Deer } \\
\text { Female } \\
(n=1)\end{array}$} & \multicolumn{2}{|c|}{ Goral } & \multicolumn{2}{|c|}{ Barking Deer } \\
\hline & & $\begin{array}{l}\text { Male } \\
(n=2)\end{array}$ & $\begin{array}{c}\text { Female } \\
(n=2)\end{array}$ & $\begin{array}{l}\text { Male } \\
(n=2)\end{array}$ & $\begin{array}{c}\text { Female } \\
(n=2)\end{array}$ \\
\hline Glucose (mg \%) & - & 66.26 & - & 94.26 & 65.39 \\
\hline Total protein $(\mathrm{g} / \mathrm{dl})$ & 7.61 & 7.24 & 4.01 & 5.56 & 5.44 \\
\hline Albumin (g/dl) & 3.32 & 2.91 & 2.24 & 3.03 & 3.55 \\
\hline Globulin (g/dl) & 4.27 & 4.30 & 1.75 & 2.50 & 1.87 \\
\hline Creatinine (g/dl) & 1.70 & 2.71 & 2.41 & 2.41 & 2.00 \\
\hline Urea (mg \%) & 18.12 & 20.30 & 21.40 & 21.07 & 28.23 \\
\hline
\end{tabular}

(C) Zoo Outreach Organisation; www.zoosprint.org Manuscript 1323; Received 28 January 2005; Revised received 28 May 2005; Finally accepted 16 January 2006 ; Date of publication 21 May 2006 June 2006 | ISSN 0973-2535 (Print edition); 0973-2551 (Online edition) 
haematological profiles of the Mountain Gazelle (Gazelle gazelle): variation with sex, age, capture method, season and anaesthesis. Journal of Wildlife Diseases 30(1): 69-76.

Schirmeister, J. (1964). Dtsch. Med. Wschr. 89: 1018.

Seal, V.S. and M. Bush (1987). Capture and chemical immobilization of cervids. In: Wemmer, C.M. (Ed.). Biology and Management of the Cervidae. Smithsonian Institute Press, Washington, D.C.

Trinder, P. (1969). Analyst. 85: 889.

Webster, D. (1977). Clinical Chemistry. 23: 663.

Wood, A.K., R.E. Short, A.E. Darling, G.L. Dusek, K.G. Sasser, and C.A. Ruder (1986). Serum assays for detecting pregnancy in mule and white tailed deer. The Journal of Wildlife Management 50: 684-867.

\section{ACKNOWLEDGEMENTS}

The authors express their gratitude to the Dean, College of Veterinary and Animal Sciences, G.B. Pant University of Agriculture and Technology, Pantnagar for providing necessary facilities for the conduct of this work. Authors are also thankful to the conservator, Pandit G.B. Pant High Altitude Zoo Nainital, for their cooperation for the smooth conduct of this work.

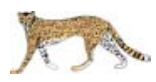

VET BRIEF ZOOS' PRINT JOURNAL 21(6): 2302

\section{A CASE OF HISTIOCYTOMA IN A LEOPARD Panthera pardus}

\section{Nath ${ }^{1}$, T.K. Pattnaik ${ }^{1}$, N. Sahoo ${ }^{2}$, V.S.C. Bose ${ }^{1}$, H.K. Mohapatra ${ }^{3}$ and R.K. Samantaray ${ }^{4}$}

\footnotetext{
${ }^{1}$ Department of Surgery, ${ }^{2}$ Regional Centre for Wildlife Health, ${ }^{3}$ Department of Pathology, Orissa Veterinary College, Orissa University of Agriculture and Technology, Bhubaneswar, Orissa 751003, India

${ }^{4}$ Nandankanan Zoological Park, Orissa
}

web supplement

Neoplasms of skin like histocytomas are common in canines. These benign tumors arise from the monocyte macrophage population of the skin (Henderson \& Brewer, 1993). The present paper reports a case of histiocytoma in the ventral aspect of neck in a leopard.

A female leopard, aged 9 years weighing about $50 \mathrm{~kg}$, at Nandankanan Zoo developed a fluctuating swelling at ventral cervical region with symptoms of periodic inappetance and respiratory distress. Parenteral administration of Cefotaxime sodium 1g (Alkem Lab) and Neurobion 9ml (Merck Lab) once daily for seven days suppressed the symptoms. The condition recurred after seven months showing similar symptoms with marked increase in swelling. Repetition of initial treatment did not produce favourable results. It was decided to anaesthetize the leopard for examination and treatment. A mixture of $0.65 \mathrm{mg}$ of atropine sulphate, $0.25 \mathrm{mg}$ of xylazine hydrochloride and $75 \mathrm{mg}$ of ketamine hydrochloride was injected intramuscularly after restraining the animal in a squeeze cage. The leopard came to recumbent position in nine minutes and was transported to the zoo hospital. Sonogram of the region was performed using a linear probe of $5 \mathrm{MHz}$ which revealed heterogenous anechoic and hypoechoic areas identifying combination of solid mass with little soft tissues. It was observed that the larynx and trachea were deviated from its normal position. A bottle of DNS was infused intravenously and the animal was intubated with an endotracheal tube of $9 \mathrm{~cm}$ ID. It was decided to enucleate the mass. A liberal skin incision was given over the mass to exteriorize it from the underlying tissues. On examination it was found that the growth was extending from hyoid bone to thoracic inlet caudally putting pressure on trachea and oesophagus. As the growth was highly vascular and in view of its proximity to vital structures around the area it was decided not to intervene further and hence the incision was closed. The animal was revived with $10 \mathrm{mg}$ of intravenous yohimbine hydrochloride and brought to sitting posture but within 20 minutes it developed cardial arrest and died. Post-mortem examination did not reveal any gross lesions any where in the body. Histopathological examination of the growth showed large, closely packed cells appeared indistinctly grouped by thin fibrous tissue. Cells showed round to oval vesciculated nuclei and prominent nucleoli. Mitotic figures were not infrequent. Cytoplasms were clear, many being vacuolar indicating it to be a histiocytoma (Image $1^{\mathrm{w}}$ ).

\section{REFERENCE}

Henderson, R.A. and W.G. Jr. Brewer (1993). Skin and subcutis, pp. 2085-2086. In: Slatter, N. (Ed.). Textbook of Small Animal Surgery. Vol. II. $2^{\text {nd }}$ Edn. W.B. Saunders Company, Philadelphia.

\section{ACKNOWLedgement}

Authors are thankful to the Deputy Director, Nandankanan Zoological Park, Baranga for according permission to do the work.

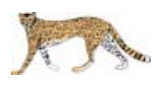

See Image $1^{\mathrm{w}}$ in the web supplement at www.zoosprint.org 